REMIGIUSZ ROSICKI

Adam Mickiewicz University in Poznań

DOI : $10.14746 /$ rie.2017.11.27

\title{
Clean and dirty energy cultures in the European Union
}

\section{Introduction}

The object of analysis in the present text is the "energy cultures" of the member states of the European Union (EU-28). The text attempts to verify the legitimacy of the claims pointing to the possibility of grouping the European Union countries according to a special kind of energy use practice (production, consumption and conversion of energy). The main goal of the presented research is the readiness to continue the analyses which feature in the energy culture studies involving quantitative methods. For instance, the studies of energy cultures involving various classification algorithms have been conducted by Petri Tapio, David Banister, Jyrki Luukkanen, Jarmo Vehmas, Risto Willamo, Agnieszka Pach-Gurgul, Bartosz Soliński, Paweł Frączek (Tapio et al., 2007, pp. 433-451; Pach-Gurgul, 2012, pp. 160-202; Pach-Gurgul, Soliński, 2013, pp. 17-30; Frączek, Majka, 2015, pp. 215-223; Rosicki, 2016, pp. 225-237).

In order to elaborate the research problem, the text includes the following research questions: (1) Is it legitimate to claim that within the EU-28 there are special "energy cultures"?, (2) If the claim of the existence of special "energy cultures" is legitimate, what features determine the division among the EU-28 countries? For the research process to be conducted, the following research hypotheses have been put up for verification: (1) It must be assumed that the differences in energy production and consumption structures in the individual EU-28 countries are a sufficient premise to establish the existence of special "energy cultures," (2) It must be assumed that the potential characteristics allowing for the division of the EU-28 countries according to specific "energy cultures" are: emission performance, production of electrical energy from solid fuels, and energy efficiency.

The posed questions and the hypotheses proposed for verification should be associated with the intention to establish the existence of the division of the EU-28 countries into "clean" and "dirty" energy cultures. The potential groupings of the countries based on the diagnostic features that would illustrate these kinds of energy cultures can be substantiated by the features of the EU-28 member states concerned with energy production, consumption and conversion, e.g. GHG emissions and commitment to the coal sector.

The work methodology is based on the application of selected methods of cluster analysis, which is a common procedure for empirical data analysis. The cluster analysis is used to sort objects (in this case - countries) or variables into unspecified groups. In the first place, the Ward's method was used; it is one of the most commonly used agglomerative clustering methods. Another method employed in the research in question is the $k$-means method, that is the non-hierarchical algorithm of cluster analysis. 
Subsequently, with the aid of the individual tests, the differences in the level of parameters between the isolated clusters of countries were analysed. Furthermore, groups of independent factors were isolated with the aid of the principal component method, as well as the scope of significant differences in the level of the isolated factors between the clusters of the EU-28 countries was pointed out (Kaufman, Rousseeuw, 2005, pp. 230-234; Stanisz, 2007, p. 122; Mirkin, 2015, pp. 75-136; Analiza czynnikowa, 2017; Analiza skupień, 2017).

For the purpose of the analysis the quantitative data from the individual EU-28 states in 2012 were used; these were presented in Table 1. The Table allows for the values of the following indexes of "energy cultures": (1) greenhouse gas emissions from energy industries, (2) greenhouse gas emissions from transport, (3) gross electricity generation from solid fuels, (4) gross electricity generation from RES, (5) share of renewable energy in fuel consumption of transport, (6) energy intensity of the economy, (7) combined heat and power generation.

\section{Concept of energy cultures and research into energy cultures}

It is next to impossible to present an exhaustive analysis of the comprehension of the concept of culture, which results from the fact that it is used in a variety of spheres and branches of science. The definitions of the concept of "culture" that are usually mentioned are of a postulative (i.e. operative) character, but - despite the multi-layered discourse on the subject - it is possible to point to several main directions or elements that matter. In the first place, attention should be drawn to the approaches to culture as a process and form of resource transformation, as well as the impact of the transformation on reality. Subsequently, culture can be approached as a special kind of the sphere of social awareness (Cf. Kłosowska, 1969; Kłosowska 1972; Keesing, 1974, pp. 73-94; Nowicka, 1991, pp. 55-88; Burszta, 1998, pp. 35-57; Gajda, 2008, pp. 17-60; Strinati, 1998, pp. 15-49). Hence, culture can be understood as all of the tangible and intangible effects of human activity. Noteworthily, such aspects of the phenomenon of culture as normativity, functionality, structurality, adaptiveness can be pointed out.

As regards the research into the energy culture, the two above-mentioned ways of approaching culture come to be reflected in the methods and techniques of the research into the issue. The first direction of research into energy culture is related to the way resources are transformed. In the case in question, it is a presentation of the characteristic features connected with production of "energy" sensu lato. Most frequently, this approach is expressed in the presentation of analyses concerned with: (1) energy production (and its diversification), (2) energy consumption (and its diversification), (3) import dependence, (4) development of new energy technologies, (5) energy use-related pollution. The other direction of research presents analyses concerned with a particular kind of awareness on the part of individuals and social groups, which can be exemplified by research into environmental awareness within the context of energy generation problems.

As regards the analyses concerned with a special kind of energy production, consumption and conversion practices, there are both qualitative and quantitative research projects. The qualitative research is usually based on the presentation of descriptive 
analyses that synthesise and generalise energy cultures. Such research results in synthetic "models" exposing dominant features of energy structures in individual states and/or groups of states (Lucki, Misiak, 2010, pp. 47-50, 72-78; Frączek, 2014, pp. 443-449). The quantitative research concerned with energy production and consumption practices can be exemplified by analyses conducted on the basis of a variety of classification algorithms. This kind of research will include the studies involving the Ward's method and the $k$-means method (Tapio et al., 2007, pp. 433-451; PachGurgul, 2012, pp. 160-202; Pach-Gurgul, Soliński, 2013, pp. 17-30; Frączek, Majka, 2015, pp. 215-223; Rosicki, 2016, pp. 225-237).

As regards the second current of research into energy cultures, that is the ones concerned with the research into awareness, environment-friendly behaviour and attitudes towards energy saving, quantitative research based on survey techniques and qualitative research based on various forms of open interviews are the most representative ones. The scientific research within this scope concerns such issues as the construction of the "model" of behaviour patterns and habits (frequently behaviour patterns among individual energy users). Furthermore, this current also features the results of the survey research targeted at a specified statistical sample selected from the population with a view to establishing the awareness, behaviour and habits concerned with the use of energy. With this goal in mind, in-depth analyses are conducted as regards the influence of socio-demographic and psychological factors on awareness, behaviour patterns and practices among energy users (Cf. Stern, Gardner, 1981, pp. 329-342; van Raaij, Verhallen, 1981, pp. 253-257; van Raaij, Verhallen, 1983a, pp. 39-63; van Raaij, Verhallen, 1983b, pp. 85-106; Stern, 2000, pp. 407-424; Lindén, Carlsson-Kanyama, Eriksson, 2006, pp. 1918-1927; Papuziński, 2006, pp. 33-40; Tuszyńska, 2007, pp. 233-236; Hłobił, 2010, pp. 87-94; Frederiks, Stenner, Hobman, 2015, pp. 573-609).

In the case of the research presented in the text, a statistical analysis of the energy cultures in the European Union member states will be employed. Such an approach to the issues does not obviate the need to present the content of the concept of "clean" and "dirty" energy cultures. If we assume that an energy culture is a special kind of energy production, consumption and conversion practices, then belonging to either "clean" or "dirty" energy cultures will be determined by the values of parameters of individual indexes characterised by individual diagnostic features of energy cultures. The diagnostic features characteristic of the "clean" or "dirty" energy use have been recognised as: (1) emission performance, (2) energy production structure, (3) energy efficiency, (4) transport fuel structure. For instance, the clean energy culture will be determined by low GHG emissions, a considerable share of renewable sources in the energy production structure, a high level of energy efficiency, as well as a considerable share of renewable sources in transport fuels. The "dirty" energy cultures will be marked by opposite tendencies.

\section{Indexes of clean and dirty energy cultures}

It has been assumed that there is a possibility of devising an operative definition of "clean" and "dirty" energy cultures. It has been agreed that an "energy culture" denotes a special kind of energy production, consumption and conversion practices 
represented by the following diagnostic features: (1) a character of emission performance, (2) a character of electrical energy production, (3) a character of the energy efficiency of the economy, (4) a character of the RES management in transport fuels. The diagnostic feature concerned with the emission performance is to be determined by two indexes: (1) the index of greenhouse gas emissions from energy industries, (2) the index of greenhouse gas emissions from transport. For the diagnostic feature concerned with the production of electrical energy to be determined, the index of gross electricity generation from solid fuels, the index of gross electricity generation from RES and the index of combined heat and power generation have been used. Another feature, that is the character of the energy efficiency of the economy, has been determined by the index of energy intensity of the economy. The last one of the diagnostic features, that is the RES management in transport fuels, is represented by the index of a share of renewable energy in fuel consumption of transport (See Table 1).

As regards the GHG emission performance, the indexes of the emission performance in individual countries have been employed, with regard to the energy conversion in the energy industry sector and in the transport sector, without calculating the ratio of the GDP value or the per capita ratio. This device is supposed to facilitate the division and grouping of countries with regard to the real GHG emissions, that is the emissions expressed in million tonnes $\mathrm{CO}_{2}$ equivalent. As regards the electrical energy production, the focus was on gross electrical energy production, as well as the share of solid fuels and renewable energy sources therein. As in the case of the first diagnostic feature, also here the "natural" index values expressed in terawatt-hours were presented. A selection of such indexes is supposed to illustrate the level of a given country's commitment to the conventional energy sector, which is often associated with a high level of emission performance, as well as the commitment to the renewable energy source sector, which is characterised by a higher level of environment-friendliness. Furthermore, the index of the percentage share of combined heat and power generation in the gross electrical energy production has been used to illustrate energy production. Such a selection of indexes with the accepted values may be disputable, since, for instance, the level of production of electrical energy from solid fuels itself does not illustrate the level of the countries' commitment to new coal technologies, whereas the percentage share of the combined heat and power generation in the gross electrical energy production does not illustrate the technological level of this type of energy conversion.

As regards the analysis of energy efficiency, use was made of the index of energy intensity of the economy, the value of which is determined by the ratio of gross energy use to the gross domestic product ( $\mathrm{kg}$ of oil equivalent/1000 EUR). The high level of the index illustrates the state, whereby the cost of energy conversion is high in relation to the actual gross domestic product. Furthermore, it may be pointed out that the differences in the level of energy intensity are likely to define the level of economic development, economic structure, technological advancement, the kind of carriers in primary energy production (Cf. Pach-Gurgul, Soliński, 2013, p. 23; Rosicki, 2016, pp. 230-231).

To diagnose the renewable energy sources management in transport, use was made of the index of the percentage share of RES in transport fuel consumption. The use of this index may be disputable given the capability of the individual member states of 
the European Union to use biofuels, also as regards the assessment of some biofuels as environment-friendly. However, it appears that the commitment on the part of the individual states to the development of the RES share in the consumption of transport fuel points to the willingness to eliminate the emissions in sectors other than the energy one - the industrial one, the agricultural one, etc. Besides, it must be pointed out that the subsequent decades will bring a transformation of the transport sector in the direction of electromobility.

Table 1

Indexes of energy cultures in the European Union member states in 2012 (EU-28)

\begin{tabular}{|c|c|c|c|c|c|c|c|}
\hline & \begin{tabular}{|c|} 
Greenho- \\
use Gas \\
Emissions \\
from energy \\
industries \\
\end{tabular} & $\begin{array}{c}\text { Greenhouse } \\
\text { Gas Emis- } \\
\text { sions from } \\
\text { Transport }\end{array}$ & \begin{tabular}{|c|} 
Gross \\
Electricity \\
Generation \\
from solid \\
fuels \\
\end{tabular} & $\begin{array}{c}\text { Gross } \\
\text { Electricity } \\
\text { Generation } \\
\text { from RES }\end{array}$ & $\begin{array}{c}\text { Share of } \\
\text { renewable } \\
\text { energy in fuel } \\
\text { consumption } \\
\text { of transport }\end{array}$ & $\begin{array}{c}\text { Energy } \\
\text { intensity of } \\
\text { the econo- } \\
\text { my }\end{array}$ & $\begin{array}{c}\text { Combined } \\
\text { heat and } \\
\text { power ge- } \\
\text { neration }\end{array}$ \\
\hline & $\begin{array}{c}\text { (Million } \\
\text { tonnes } \mathrm{CO}_{2} \\
\text { equivalent) }\end{array}$ & $\begin{array}{c}\text { (Million } \\
\text { tonnes } \mathrm{CO}_{2} \\
\text { equivalent) }\end{array}$ & (TWh) & (TWh) & $(\%)$ & $\begin{array}{c}\text { (kg of oil } \\
\text { equivalent/ } \\
1 \text { 000 EUR) }\end{array}$ & $\begin{array}{l}\text { (\% of gross } \\
\text { electricity } \\
\text { generation) }\end{array}$ \\
\hline $\mathrm{BE}$ & 23.45 & 24.93 & 3.39 & 11.76 & 4.40 & 167.40 & 15.60 \\
\hline $\mathrm{BG}$ & 31.62 & 8.45 & 22.88 & 6.08 & 0.30 & 669.90 & 5.90 \\
\hline $\mathrm{CZ}$ & 59.23 & 16.80 & 44.45 & 8.80 & 5.60 & 355.70 & 13.10 \\
\hline DK & 16.77 & 12.16 & 10.57 & 14.84 & 5.50 & 86.40 & 48.80 \\
\hline $\mathrm{DE}$ & 363.54 & 154.60 & 277.13 & 149.55 & 6.90 & 128.90 & 12.60 \\
\hline EE & 13.08 & 2.29 & 9.80 & 1.48 & 0.30 & 478.40 & 9.70 \\
\hline IE & 12.77 & 10.83 & 8.10 & 5.46 & 4.10 & 82.50 & 7.60 \\
\hline EL & 54.68 & 16.23 & 31.12 & 10.34 & 1.00 & 165.10 & 3.90 \\
\hline ES & 91.96 & 80.64 & 55.07 & 90.58 & 0.40 & 137.00 & 8.90 \\
\hline FR & 52.58 & 132.52 & 18.92 & 88.23 & 7.10 & 142.80 & 2.70 \\
\hline HR & 5.52 & 5.65 & 2.24 & 5.23 & 0.40 & 225.60 & 19.90 \\
\hline IT & 127.73 & 106.04 & 49.14 & 94.20 & 5.80 & 119.60 & 12.00 \\
\hline CY & 3.55 & 2.08 & 0.00 & 0.26 & 0.00 & 167.50 & 0.60 \\
\hline LV & 1.86 & 2.79 & 0.00 & 4.11 & 3.10 & 328.60 & 34.50 \\
\hline LT & 4.40 & 4.58 & 0.00 & 1.70 & 4.80 & 292.10 & 36.10 \\
\hline LU & 1.03 & 6.47 & 0.00 & 1.37 & 2.20 & 134.00 & 11.70 \\
\hline $\mathrm{HU}$ & 16.72 & 10.64 & 6.34 & 2.65 & 4.60 & 268.70 & 13.40 \\
\hline MT & 2.05 & 0.53 & 0.00 & 0.02 & 3.10 & 171.30 & 0.00 \\
\hline NL & 60.81 & 36.70 & 24.21 & 12.54 & 5.00 & 149.40 & 33.70 \\
\hline AT & 12.52 & 21.58 & 4.41 & 55.12 & 7.80 & 124.20 & 14.40 \\
\hline PL & 169.56 & 46.74 & 134.65 & 17.31 & 6.10 & 298.00 & 16.70 \\
\hline PT & 17.45 & 15.71 & 13.09 & 20.41 & 0.40 & 148.30 & 13.90 \\
\hline RO & 32.56 & 15.24 & 22.90 & 15.20 & 4.00 & 378.90 & 11.40 \\
\hline SI & 6.05 & 5.77 & 5.15 & 4.51 & 2.90 & 227.50 & 7.50 \\
\hline SK & 8.85 & 6.96 & 3.42 & 5.81 & 4.80 & 329.30 & 78.60 \\
\hline FI & 20.72 & 12.21 & 10.78 & 28.54 & 0.40 & 207.70 & 34.50 \\
\hline SE & 10.59 & 19.00 & 0.88 & 98.44 & 12.90 & 148.30 & 9.60 \\
\hline UK & 190.49 & 114.74 & 143.18 & 44.23 & 3.70 & 105.50 & 6.00 \\
\hline
\end{tabular}

Source: Own study on the basis of Eurostat, IEA data. 


\section{Attempt at grouping states and analysis of factors}

\subsection{Ward's method and k-means method}

In order to group the countries, with regard to the values of the specified indexes, selected methods of cluster analysis were used: (1) the Ward's method and (2) the $k$-means method. Before the analyses were performed, all index values had been standardised. As regards the Ward's method, the distance between the objects was measured with the squared Euclidean distance. On the basis of the hierarchical cluster analysis performed according to the Ward's method and the dendrogram, two clusters of the European Union member states were formed. In order to confirm the predictions as to the number of clusters, the analysis of clusters was performed, with the method of $k$-means for the optimal cluster number of 2 (See Table 2).

Table 2

Country groupings according to energy cultures

\begin{tabular}{|l|l||}
\hline Cluster 1: & \multicolumn{1}{|c|}{ Elements of clusters defined with the ward's method and the $\boldsymbol{k}$-means method } \\
\hline Cluster 2: & $\begin{array}{l}\text { BE, BG, CZ, DK, EE, IE, EL, HR, CY, LV, LT, LU, HU, MT, NL, AT, PT, RO, SI, SK, FI, } \\
\text { SE. }\end{array}$ \\
\hline
\end{tabular}

Source: Own study.

The first cluster included the following countries: (1) Germany, (2) Spain, (3) France, (4) Italy, (5) Poland and (6) the United Kingdom. The second cluster included: (1) Belgium, (2) Bulgaria, (3) the Czech Republic, (4) Denmark, (5) Estonia, (6) Ireland, (7) Greece, (8) Croatia, (9) Cyprus, (10) Latvia, (11) Lithuania, (12) Luxembourg, (13) Hungary, (14) Malta, (15) the Netherlands, (16) Austria, (17) Portugal, (18) Romania, (19) Slovenia, (20) Slovakia, (21) Finland and (22) Sweden.

\subsection{The difference in the level of parameters between country clusters}

Before the analysis was performed, the premises of the variance analysis (ANOVA) had been checked. Given the lack of the equivalence of the groups (6 and 22), the lack of the compliance of the distribution of the variables with the normal distribution, and the heterogeneity of variance in the individual groups, verified with Levene's test, it was determined that non-parametric tests will be carried out with a view to verifying the differences between the clusters (See Table 3).

In order to check if there were any significant differences between the countries in the first cluster and the countries in the second cluster, a number of Mann-Whitney $U$ tests was conducted and the index of $r$ effect strength was calculated, whereby the results are interpreted as follows: $0-0.2$ - slight, $0.2-0.5$ - weak, $0.5-0.8$ - moderate, $0.8-1$ - strong (See Table 3). 
Table 3

Descriptive statistics, ANOVA results and Mann-Whitney $U$ test results for the level of parameters with the breakdown according to country clusters

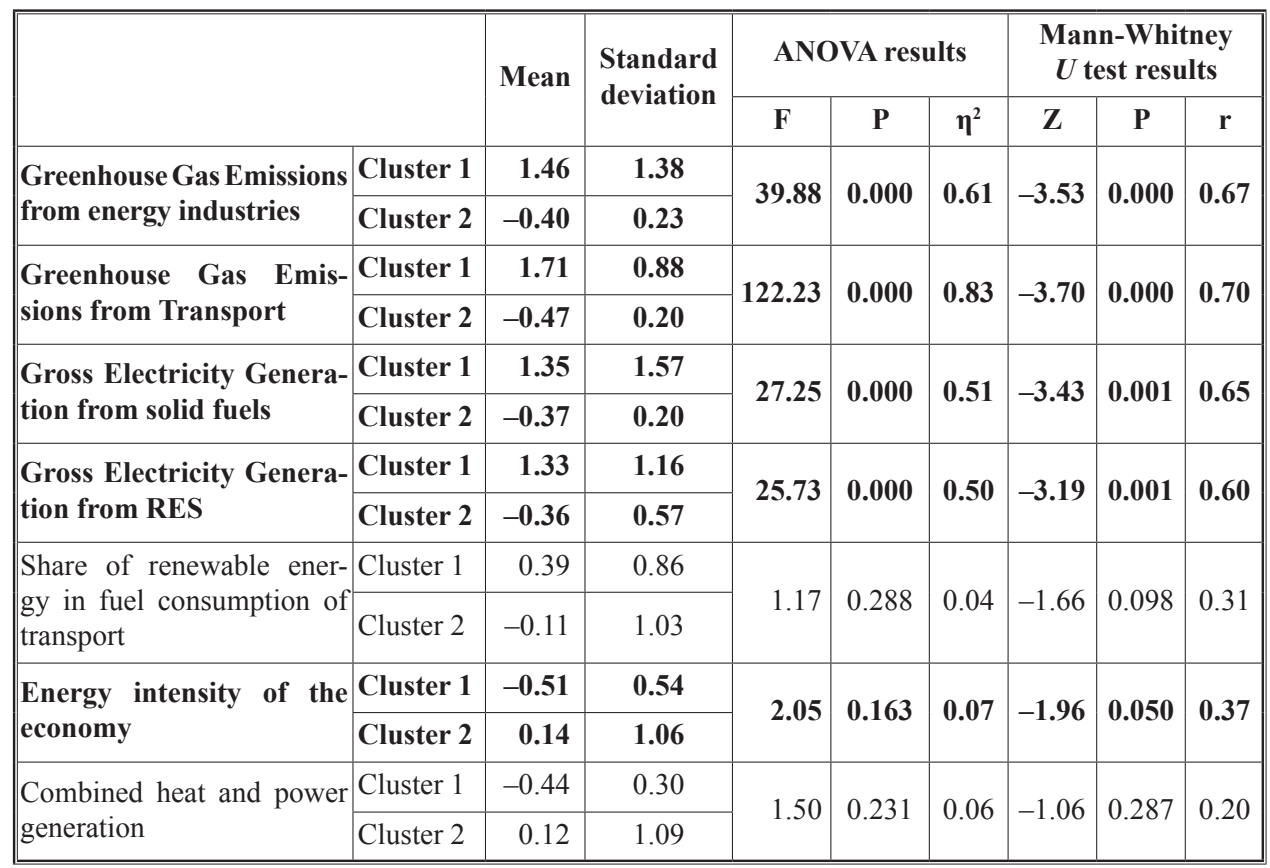

Source: Own study.

On the basis of the analysis results it was found that there are essential differences in the mean level of the index of greenhouse gas emissions from energy industries for the countries in the first cluster and the ones in the second cluster $(Z=-3.53 ; p<0.001$; $r=0.67)$. The mean for the level of this parameter was higher for the countries in the first cluster than for the ones in the second cluster (Cluster 1: $\mathrm{M}=1.46$; $\mathrm{SD}=1.39$; Cluster 2: $\mathrm{M}=-0.40 ; \mathrm{SD}=0.23)$. The strength of the relationship between the variables was moderate (See Table 3, Figure 1 and 2).

As in the case of the emission performance of the energy sector, also in the case of the emission performance of the transport sector the analysis showed essential differences in the mean level of the value of the index of greenhouse gas emissions from transport for the countries in the first cluster and the countries in the second cluster $(Z=-3.70 ; p<0.001 ; r=0.70)$. The mean for the level of this parameter was higher for the countries in the first cluster than for the countries in the second cluster (Cluster $1: \mathrm{M}=1.71$; $\mathrm{SD}=0.88$; Cluster $2: \mathrm{M}=-0.47$; $\mathrm{SD}=0.20$ ). It must also be pointed out that the strength of the relationship between these variables was moderate (See Table 3, Figure 1 and 2).

With regard to the analysis it was concluded that there are essential differences in the level of the values of the index of gross electricity generation from solid fuels and the index of gross electricity generation from RES between the countries in the first cluster and the countries in the second cluster (the former index: $Z=-3.43$; 
$\mathrm{p}<0.01 ; \mathrm{r}=0.65$; the latter index: $\mathrm{Z}=-3.19 ; \mathrm{p}<0.01 ; \mathrm{r}=0.60)$. The mean for the level of these parameters was higher for the countries in the first cluster than for the countries in the second cluster (for the index of gross electricity generation from solid fuels in Cluster 1: $\mathrm{M}=1.35$; $\mathrm{SD}=1.57$; for the index of gross electricity generation from solid fuels in Cluster 2 : $\mathrm{M}=-0.37$; $\mathrm{SD}=0.20$; for the index of gross electricity generation from RES in Cluster $1: \mathrm{M}=1.33$; $\mathrm{SD}=1.16$; for the index of gross electricity generation from RES in Cluster 2: $\mathrm{M}=-0.36$; $\mathrm{SD}=0.57$ ). The strength of the relationship between these variables was moderate (See Table 3, Figure 1 and 2).

It must also be pointed out that the analysis with the aid of Mann-Whitney $U$ test showed essential differences in the level of the values of the index of energy intensity of the economy between the countries in the first cluster and the countries in the second cluster $(Z=-1.96 ; p<0.05 ; r=0.37)$. The mean for the level of this parameter was lower for the countries in the first cluster than for the countries in the second cluster (Cluster 1: $\mathrm{M}=-0.51 ; \mathrm{SD}=0.54$; Cluster 2: $\mathrm{M}=0.14 ; \mathrm{SD}=1.06$ ). Still, in this case, the strength of the relationship between these variables was weak. Besides, it is noteworthy that the analysis did not show any essential differences in the level of the value of the index of share of renewable energy in fuel consumption of transport and the level of the value of the index of combined heat and power generation between the country clusters (for the former index: $Z=-1.66 ; \mathrm{p}=0.098$; $\mathrm{r}=0.31$; for the latter index: $\mathrm{Z}=-1.06 ; \mathrm{p}=0.287 ; \mathrm{r}=0.20$ ) (See Table 3, Figure 1 and 2).

Figure 1. Graph of the standardised means for the parameters

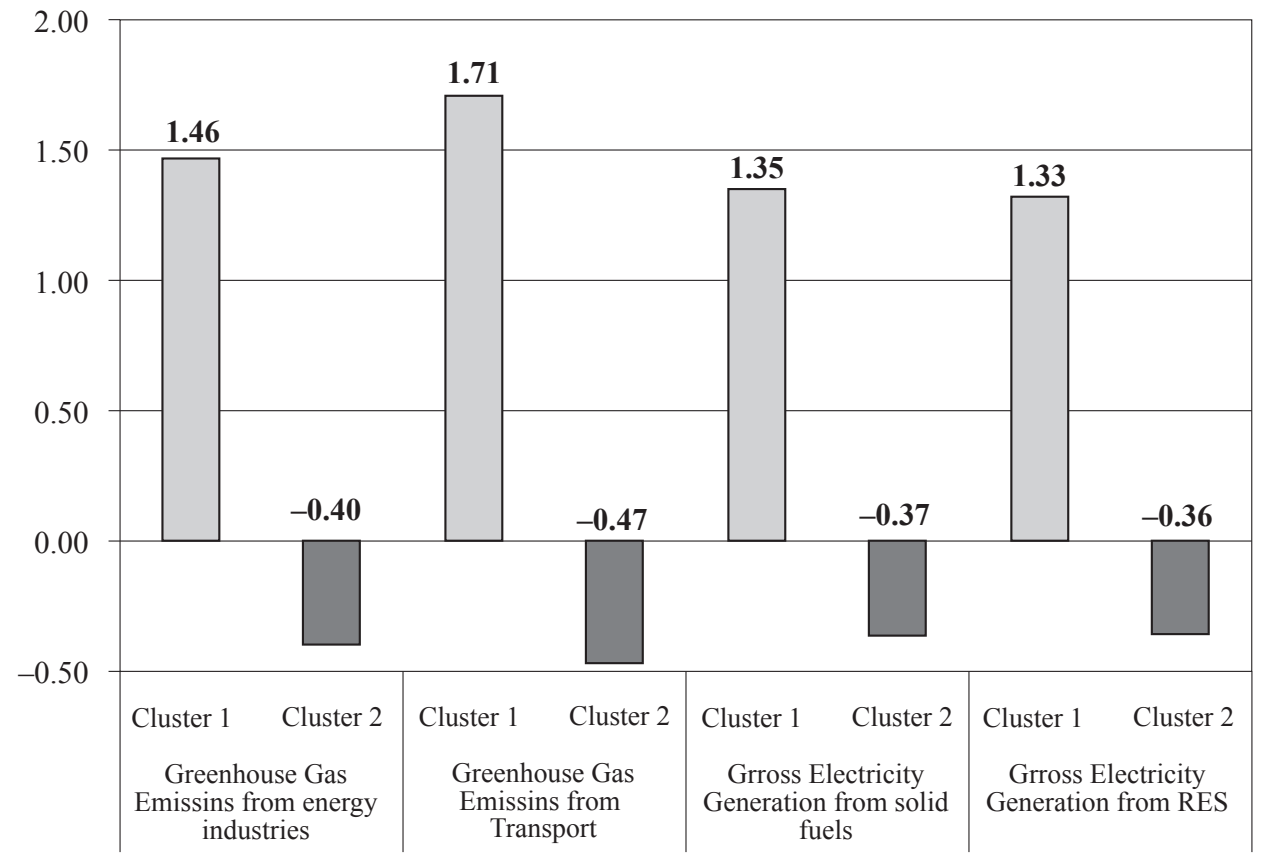

Source: Own study. 
Figure 2. Graph of the standardised means for the parameters

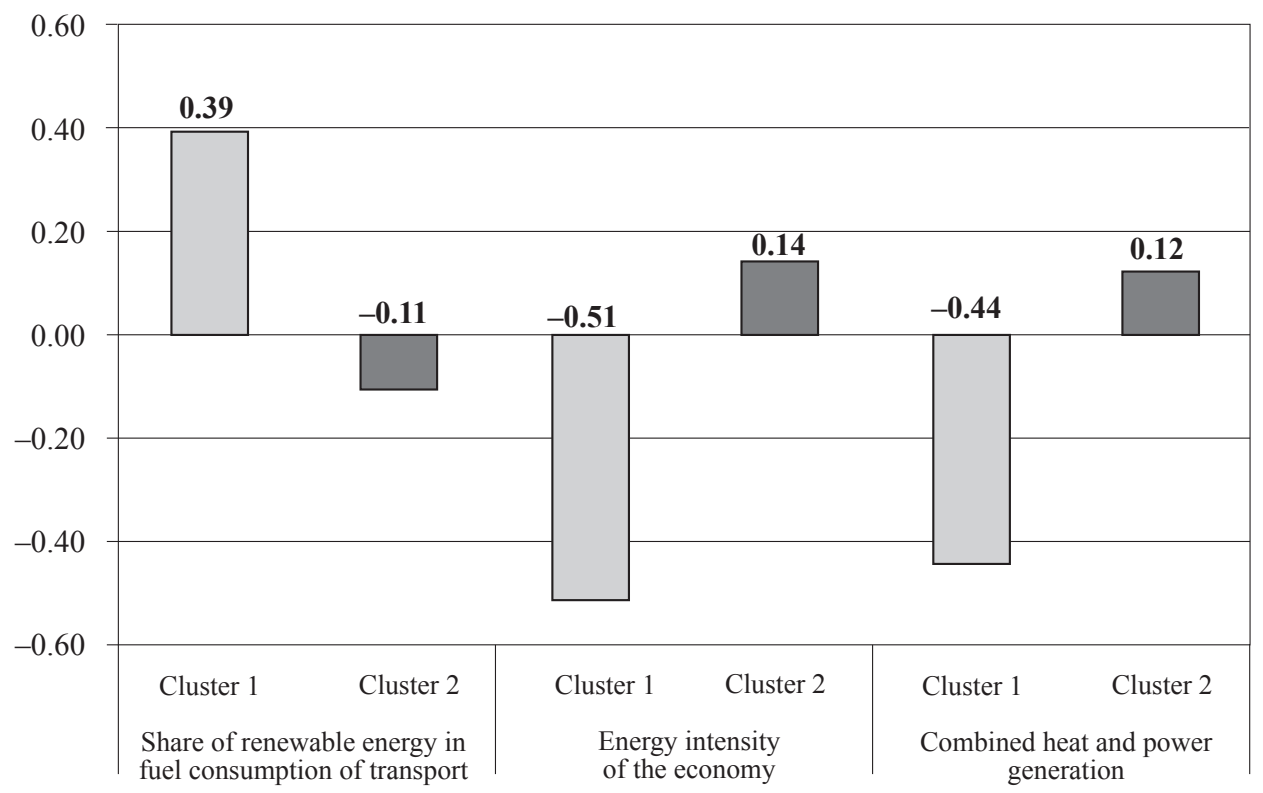

Source: Own study.

\subsection{Isolation of groups of independent factors}

In order to isolate groups of independent factors, a factor analysis was performed, using the principal component method and a Varimax rotation. On the basis of the results of Bartlett's test of sphericity it was concluded that there were relationships between the parameters, and so it was worthwhile performing a factor analysis in order to isolate groups of related parameters: $\chi^{2}(21)=167.02 ; p<0.001$. The measure of sampling adequacy was $\mathrm{KMO}=0.688$, and on this basis it was concluded that the reduction in sizes produced significant results (See Table 4). With the Cattell's criterion based on the analysis of the scree plot it was found that 2 components should be isolated.

Table 4

Pearson correlation results

\begin{tabular}{|c|c|c|c|c|c|c|c|c|}
\hline & \multicolumn{2}{|c|}{$\begin{array}{l}\text { Greenhouse Gas } \\
\text { Emissions from }\end{array}$} & \multicolumn{2}{|c|}{$\begin{array}{c}\text { Gross Electri- } \\
\text { city Genera- } \\
\text { tion from }\end{array}$} & \multirow{2}{*}{$\begin{array}{c}\text { Share of } \\
\text { renewable } \\
\text { energy in fuel } \\
\text { consumption } \\
\text { of transport }\end{array}$} & \multirow{2}{*}{$\begin{array}{c}\text { Energy } \\
\text { intensity } \\
\text { of the } \\
\text { economy }\end{array}$} & \multirow{2}{*}{$\begin{array}{c}\text { Combined } \\
\text { heat and } \\
\text { power } \\
\text { generation }\end{array}$} \\
\hline & & $\begin{array}{c}\text { energy } \\
\text { industries }\end{array}$ & $\begin{array}{c}\text { Trans- } \\
\text { port }\end{array}$ & $\begin{array}{l}\text { solid } \\
\text { fuels }\end{array}$ & RES & & & \\
\hline 1 & 2 & 3 & 4 & 5 & 6 & 7 & 8 & 9 \\
\hline $\begin{array}{l}\text { Gree } \mathrm{nh} \text { ouse } \\
\text { Gas Emissions }\end{array}$ & $\begin{array}{l}\text { Pearson } \\
\text { correlation }\end{array}$ & 1 & 0.82 & 0.99 & 0.67 & 0.23 & -0.19 & -0.16 \\
\hline $\begin{array}{l}\text { from energy in- } \\
\text { dustries }\end{array}$ & Significance & - & 0.000 & 0.000 & 0.000 & 0.230 & 0.336 & 0.417 \\
\hline
\end{tabular}




\begin{tabular}{|c|c|c|c|c|c|c|c|c|}
\hline 1 & 2 & 3 & 4 & 5 & 6 & 7 & 8 & 9 \\
\hline \multirow{2}{*}{$\begin{array}{l}\text { Greenhouse Gas } \\
\text { Emissions from } \\
\text { Transport }\end{array}$} & $\begin{array}{l}\text { Pearson } \\
\text { correlation }\end{array}$ & & 1.00 & 0.75 & 0.83 & 0.31 & -0.36 & -0.23 \\
\hline & Significance & & - & 0.000 & 0.000 & 0.105 & 0.060 & 0.245 \\
\hline \multirow{2}{*}{$\begin{array}{l}\text { Gross Electri- } \\
\text { city Generation } \\
\text { from solid fuels }\end{array}$} & $\begin{array}{l}\text { Pearson } \\
\text { correlation }\end{array}$ & & & 1.00 & 0.60 & 0.20 & -0.14 & -0.15 \\
\hline & Significance & & & - & 0.001 & 0.305 & 0.492 & 0.445 \\
\hline \multirow{2}{*}{$\begin{array}{l}\text { Gross Electri- } \\
\text { city Generation } \\
\text { from RES }\end{array}$} & $\begin{array}{l}\text { Pearson } \\
\text { correlation }\end{array}$ & & & & 1.00 & 0.50 & -0.39 & -0.20 \\
\hline & Significance & & & & - & 0.006 & 0.042 & 0.312 \\
\hline \multirow{2}{*}{$\begin{array}{l}\text { Share of rene- } \\
\text { wable energy in } \\
\text { fuel consump- } \\
\text { tion of transport }\end{array}$} & $\begin{array}{l}\text { Pearson } \\
\text { correlation }\end{array}$ & & & & & 1.00 & -0.28 & 0.10 \\
\hline & Significance & & & & & - & 0.149 & 0.599 \\
\hline \multirow[t]{2}{*}{$\begin{array}{l}\text { Energy intensity } \\
\text { of the economy }\end{array}$} & $\begin{array}{l}\text { Pearson } \\
\text { correlation }\end{array}$ & & & & & & 1.00 & 0.08 \\
\hline & Significance & & & & & & - & 0.679 \\
\hline \multirow{2}{*}{$\begin{array}{l}\text { Combined heat } \\
\text { and power ge- } \\
\text { neration }\end{array}$} & $\begin{array}{l}\text { Pearson } \\
\text { correlation }\end{array}$ & & & & & & & 1.00 \\
\hline & Significance & & & & & & & - \\
\hline
\end{tabular}

Source: Own study.

Given the fact that the method of Varimax rotation was used, a rotated component matrix was presented. The results in the matrix were sorted according to the values of factor loadings, with the values lower than 0.3 being hidden (See Table 5). It follows from the rotated component matrix that the individual factors came to be composed of the following variables:

- Factor 1 [Gas Emissions and Gross Electricity Generation]: Greenhouse Gas Emissions from energy industries, Greenhouse Gas Emissions from energy Transport, Gross Electricity Generation from solid fuels, Gross Electricity Generation from RES.

- Factor 2 [Renewable energy in transport and Energy intensity of the economy]: Share of renewable energy in fuel consumption of transport, Energy intensity of the economy.

Table 5

\section{Rotated component matrix}

\begin{tabular}{||l|r|r||}
\hline \multirow{2}{*}{} & \multicolumn{2}{|c|}{ Component } \\
\cline { 2 - 3 } & $\mathbf{1}$ & $\mathbf{2}$ \\
\hline Greenhouse Gas Emissions from energy industries & $\mathbf{0 . 9 4}$ & \\
\hline Greenhouse Gas Emissions from Transport & $\mathbf{0 . 9 2}$ & \\
\hline Gross Electricity Generation from solid fuels & $\mathbf{0 . 8 6}$ & 0.35 \\
\hline Gross Electricity Generation from RES & $\mathbf{0 . 7 2}$ & 0.54 \\
\hline Share of renewable energy in fuel consumption of transport & -0.43 & $\mathbf{0 . 3 3}$ \\
\hline Energy intensity of the economy & & $\mathbf{0 . 8 2}$ \\
\hline Combined heat and power generation & & -0.66 \\
\hline
\end{tabular}

Source: Own study. 
As a result of the conducted research, the variable of combined heat and power generation was removed from further analysis. On the basis of a hierarchical cluster analysis with the aid of the Ward's method for the squared Euclidean distance, two clusters of the European Union member states were isolated. In order to verify the predictions, a cluster analysis was performed with the aid of the $-k$-means method for the cluster number of 2 , and the result was a division of countries identical with the one presented above in the text, that is in the analysis performed for all the parameters included in Table 1.

\subsection{Differences in the level of the isolated factors between country groupings}

In order to establish essential differences in the level of the factors between the countries in the first cluster and the countries in the second cluster, non-parametric Mann-Whitney $U$ tests were run, on account of the failure to fulfil the assumptions of the ANOVA analysis (See Table 6).

Table 6

Descriptive statistics, ANOVA results and Mann-Whitney $U$ test results for the level of factors, with the division into country clusters

\begin{tabular}{|c|c|c|c|c|c|c|c|c|c|}
\hline & & \multirow[t]{2}{*}{ Mean } & \multirow{2}{*}{$\begin{array}{l}\text { Standard } \\
\text { deviation }\end{array}$} & \multicolumn{3}{|c|}{ ANOVA results } & \multicolumn{3}{|c|}{$\begin{array}{c}\text { Mann-Whitney } \\
U \text { test results }\end{array}$} \\
\hline & & & & $\mathbf{F}$ & p & $\eta^{2}$ & $\mathbf{Z}$ & p & $\mathbf{R}$ \\
\hline \multirow{2}{*}{$\begin{array}{l}\text { Gas Emissions and Gross } \\
\text { Electricity Generation }\end{array}$} & Cluster 1 & 1.46 & 1.02 & \multirow{2}{*}{68.54} & \multirow{2}{*}{0.000} & \multirow{2}{*}{0.73} & \multirow{2}{*}{-3.70} & \multirow{2}{*}{0.000} & \multirow{2}{*}{0.70} \\
\hline & Cluster 2 & -0.40 & 0.21 & & & & & & \\
\hline \multirow{2}{*}{$\begin{array}{l}\text { Renewable energy in trans- } \\
\text { port and Energy intensity } \\
\text { of the economy }\end{array}$} & Cluster 1 & -0.06 & 0.56 & \multirow{2}{*}{0.03} & \multirow{2}{*}{0.791} & \multirow{2}{*}{0.00} & \multirow{2}{*}{-0.22} & \multirow{2}{*}{0.849} & \multirow{2}{*}{0.04} \\
\hline & Cluster 2 & 0.02 & 0.62 & & & & & & \\
\hline
\end{tabular}

Source: Own study.

With regard to the performed analysis, it should be noted that there are essential differences in the mean level of the index of gas emissions and gross electricity generation for the countries in the first cluster and the countries in the second cluster $(Z=-3.70 ; p<0.001 ; r=0.70)$. The performed analysis showed that the mean for the level of this factor was higher for the countries in the first cluster than for the countries in the second cluster (Cluster 1: $M=1.46 ; S D=1.02$; Cluster 2: $M=-0.40 ; S D=0.21$ ). The relationship between the variables was moderate (See Table 6, Figure 3 and 4).

Furthermore, it is noteworthy that the performed analysis did not show any essential differences in the level of the factor of renewable energy in transport and the one of energy intensity of the economy between the countries in the first cluster and the countries in the second cluster $(Z=-0.22 ; p=849 ; r=0.04)$. It can be demonstrated that the level of this factor was similar in both the clusters (Cluster 1: $\mathrm{M}=-0.06$; $\mathrm{SD}=0.56$; Cluster 2: $\mathrm{M}=0.02 ; \mathrm{SD}=0.62)($ See Table 6, Figure 3 and 4$)$. 
Figure 3. Graph of the standardised means for the factors of gas emissions and gross electricity generation

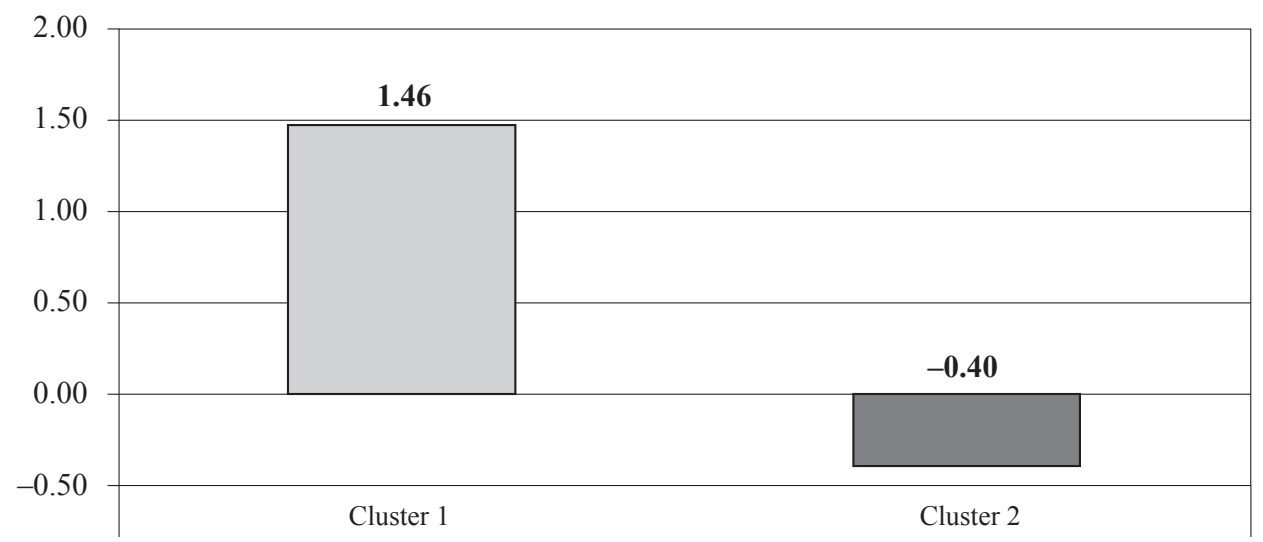

Source: Own study.

Figure 4. Graph of the standardised means for the factors of renewable energy in transport and energy intensity of the economy

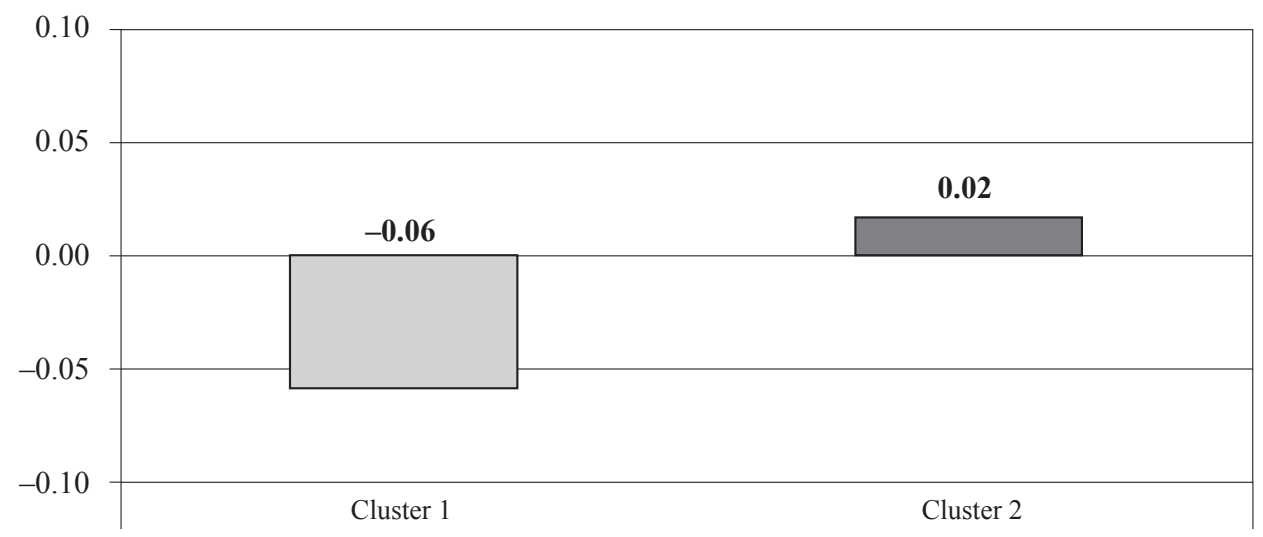

Source: Own study.

\section{Ending and conclusions}

The main goal of analysis presented in the text was to continue the research into energy cultures with the aid of a variety of classification algorithms. Within the research process, the following research hypotheses were proposed for verification: (1) It should be assumed that the differences in the energy production and consumption structures in the individual EU-28 member states constitute a sufficient premise to establish the existence of special "energy cultures," (2) It should be assumed that the potential features allowing for the division of the EU-28 member states into specified "energy cultures" are: emission performance, production of electrical energy from solid fuels and energy efficiency. The individual hypotheses were linked with the following conclusions: 


\section{(1) Conclusions}

With regard to the conducted research it must be concluded that the assumption concerned with the existence of special "energy cultures" is well-founded. On the basis of a hierarchical cluster analysis performed with the aid of the Ward's method, a dendrogram and a cluster analysis performed with the aid of $k$-means method, two clusters of EU-28 countries were isolated. The first cluster included: Germany, Spain, France, Italy, Poland and the United Kingdom. The second cluster included: Belgium, Bulgaria, the Czech Republic, Denmark, Estonia, Ireland, Greece, Croatia, Cyprus, Latvia, Lithuania, Luxembourg, Hungary, Malta, the Netherlands, Austria, Portugal, Romania, Slovenia, Slovakia, Finland and Sweden. It is interesting to note that the two isolated clusters are characterised by non-equivalence (i.e. they differ in the number of component elements), and unlike other research (though involving different diagnostic features and indexes characteristic thereof), e.g. the research by Petri Tapio and his team, no stable relationships between specified diagnostic features and a unique "geographic location or historical standing" were found. Hence, on account of the adopted diagnostic features and the indexes of energy cultures, no divisions were delineated to come up with such energy cultures as a "French" one, a "Scandinavian" one, a "southern-European" one, etc. (Cf. Tapio et al., 2007, pp. 433-451; Frączek, 2014, pp. 443-449; Rosicki, 2016, pp. 225-237).

Furthermore, it should be noted that the countries in the first cluster belong to the group of major electrical energy producers in the European Union, which given the applied indexes may substantially affect the results of country grouping. For instance, Germany - the biggest producer of electrical energy - is at the same time the biggest producer of electrical energy from solid fuels and the biggest producer of electrical energy from renewable sources. The large scale of electrical energy production in Germany makes this country the biggest GHG emitter in the energy sector

\section{(2) Conclusions}

With regard to the results of the Mann-Whitney $U$ test, which are presented in Table 3 , it should be noted that the two isolated clusters of the European Union member states differed in the level of the following parameters: (1) greenhouse gas emissions from energy industries (a higher level of the mean value for this parameter characterised the countries in the first cluster); (2) greenhouse gas emissions from transport (a higher level of the mean value for this parameter characterised the countries in the first cluster); (3) gross electricity generation from solid fuels (a higher level of the mean value for this parameter characterises the countries in the first cluster); (4) gross electricity generation from RES (a higher level of the mean value for this parameter characterises the countries in the first cluster); (5) energy intensity of the economy (a higher level of the mean value for this parameter characterises the countries in the second cluster).

Furthermore, with regard to the application of Mann-Whitney $U$ non-parametric tests, the existence of essential differences in the level of the factors between the countries in the first cluster and the countries in the second cluster was established. In the case of the 
factor of gas emissions and gross electricity generation, the mean value of the level of this factor was higher for the countries in the first cluster than for the countries in the second cluster. At the same time, the analysis did not show any significant differences in the value level of the factor of renewable energy in transport and energy intensity of the economy between the countries in the first cluster and the countries in the second cluster.

The assumption made in the text was that the possibility of demonstrating the existence of the "clean" energy culture was to be determined by low GHG emissions, a substantial share of renewable sources in the energy production structure, a high level of energy efficiency and a considerable share of renewable sources in transport fuels. Conversely, the "dirty" energy cultures present the opposite case. With the comparative analysis of the mean values of individual parameters for the clusters, it must be pointed out that: (1) the mean value of the parameters concerned with emission performance will be higher in the first cluster than in the second cluster, (2) the mean value of the parameter concerned with the share of RES in the energy production will be higher in the first cluster than in the second cluster, (3) the mean value of the parameter concerned with energy efficiency will be higher in the first cluster than in the second cluster. As regards the combined heat and power generation and the RES share in transport, the analysis did not show any significant difference in the level of the values of these indexes between the clusters.

While it is difficult - on the basis of the adopted premises - to assume that there is in fact a clear-cut division into "clean" and "dirty" energy cultures, following the selected clustering methods, it is possible to clearly demonstrate that there is a division into special kinds of "energy cultures" in the European Union. Still, if we were to focus on the values of the three indexes only, that is the index of greenhouse gas emissions from energy industries, the index of greenhouse gas emissions from transport and the index of gross electricity generation from solid fuels, then the countries in the first cluster would have to be termed countries with the "dirty" energy cultures. For instance, the countries in the first cluster - excluding France - belong to the group of the biggest GHG emitters in the energy sector; also, these countries belong to the group of the biggest GHG emitters in the transport sector; moreover, these countries - excluding France - are the biggest producers of electrical energy from solid fuels.

\section{Bibliography}

Analiza czynnikowa, http://www.statsoft.pl/textbook/stathome_stat.html?http\%3A\%2F\%2Fwww. statsoft.pl\%2Ftextbook\%2Fstfacan.html, 10.05.2017.

Analiza skupień(2017), http://www.statsoft.pl/textbook/stathome_stat.html?http\%3A\%2F\%2Fwww. statsoft.pl\%2Ftextbook\%2Fstcluan.html, 10.05.2017.

Burszta W. J. (1998), Antropologia kultury, Zysk i S-ka, Poznań.

Frączek P. (2014), Kultura energetyczna krajów nordyckich, „Nierówności Społeczne a Wzrost Gospodarczy", no. 39.

Frączek P., Majka A. (2015), Kultura energetyczna krajów Unii Europejskiej, „Nierówności Społeczne a Wzrost Gospodarczy", no. 39.

Frederiks E. R., Stenner K., Hobman E. V. (2015), The Socio-Demographic and Psychological Predictors of Residential Energy Consumption: A Comprehensive Review, „Energies”, no. 8. 
Gajda J. (2008), Antropologia kulturowa. Wprowadzenie do wiedzy o kulturze, Impuls, Kraków.

Hłobił A. (2010), Teoria i praktyka edukacji ekologicznej na rzecz zrównoważonego rozwoju, „Problemy Ekorozwoju”, vol. 5, no. 2.

Kaufman L., Rousseeuw P. J. (2005), Finding Groups in Data An Introduction to Cluster Analysis, John Wiley \& Sons, Inc., New Jersey.

Keesing R. M. (1974), Theories of Culture, “Annual Review of Anthropology”, no. 3.

Kłosowska A. (1969), Z historii i socjologii kultury, PWN, Warszawa.

Kłosowska A. (1972), Społeczne ramy kultury, PWN, Warszawa.

Lindén A.-L., Carlsson-Kanyama A., Eriksson B. (2006), Efficient and inefficient aspects of residential energy behaviour: What are the policy instruments for change?, „Energy Policy”, no. 34.

Łucki Z., Misiak W. (2012), Energetyka a społeczeństwo. Aspekty socjologiczne, PWN, Warszawa.

Mirkin B. (2005), Clustering for Data Mining A Data Recovery Approach, Taylor \& Francis Group, Boca Raton-London-New York-Singapore.

Nowicka E. (1991), Świat człowieka - świat kultury, PWN, Warszawa.

Pach-Gurgul A. (2012), Jednolity rynek energii elektrycznej w Unii Europejskiej w kontekście bezpieczeństwa energetycznego Polski, Difin, Warszawa.

Pach-Gurgul A., Soliński B. (2013), Kultura energetyczna kraju jako czynnik determinujacy ,nowa politykę energetycznq" Unii Europejskiej, „Zarządzanie Publiczne”, no. 1.

Papuziński A. (2006), Świadomość ekologiczna w świetle teorii i praktyki. Zarys politologicznego modelu świadomości ekologicznej, „Problemy Ekorozwoju”, vol. 1, no. 1.

Van Raaij W. F., Verhallen T. M. M. (1981), Household behavior and the use of natural gas for home heating, , Journal of Consumer Research”, vol. 8.

Van Raaij W. F., Verhallen T. M. M. (1983a), A behavioral model of residential energy use, „Journal of Economic Psychology", vol. 3, issue 1.

Van Raaij W. F., Verhallen T. M. M. (1983b), Patterns of residential energy behavior, „Journal of Economic Psychology", vol. 4, issues 1-2.

Rosicki R. (2016), Energy Cultures in the European Union, „Przegląd Strategiczny”, no. 9.

Stanisz A. (2007), Przystepny kurs statystyki z zastosowaniem STSTISTICA PL na przykładach z medycyny, t. 3: Analizy wielowymiarowe, StatSoft, Kraków.

Stern P. C. (2000), Towards coherent theory of environmental friendly behavior, „Journal of Social Issues", vol. 56, no. 3.

Stern P. C., Gardner G. T. (1981), Psychological research and energy policy, „American Psychologist", vol. 36 , no. 4.

Strinati D. (1998), Wprowadzenie do kultury popularnej, Zysk i S-ka, Poznań.

Tapio P., Banister D., Luukkanen J., Vehmas J., Willamo R. (2007), Energy and transport in comparison: Immaterialisation, dematerialisation and decarbonisation in the EU15 between 1970 and 2000, „Energy Policy”, vol. 35, Issue 1.

Tuszyńska L. (2007), Świadomość środowiskowa społeczeństwa polskiego, „Problemy Ekologii”, no. 5 .

\section{Summary}

The object of analysis in the text are "energy cultures" in the member states of the European Union (EU-28). The text attempts to verify the legitimacy of the statements pointing to the possibility of grouping the European Union member states according to a special kind of energy use practices. 
In order to elaborate the research problem the text features the following research questions: (1) Is it legitimate to claim that within the EU-28 there are special "energy cultures"?, (2) If the claim of the existence of special "energy cultures" is legitimate, what features determine the division among the EU-28 countries? These questions should be associated with the intention to establish the existence of the division of the EU-28 states into "clean" and "dirty" energy cultures. Such a division can be substantiated by individual features of the EU-28 member states, related to energy production, consumption and conversion, e.g. GHG emissions and the commitment to the coal sector.

For the adopted premises to be verified, the analysis employed one of the agglomerative methods (i.e. the Ward's method) and one of the methods for optimising a given group of objects (i.e. the $k$-means method). Besides, with the aid of individual tests, the differences in the level of parameters between the isolated clusters of countries were analysed. Furthermore, with the aid of the principal component method groups of independent factors were isolated, and the scope of essential differences in the level of the isolated factors between the grouped EU-28 member states was determined.

Key words: energy cultures, clean energy cultures, dirty energy cultures, energy culture indexes, energy policy, European Union, cluster analysis

\section{Czyste i brudne kultury energetyczne Unii Europejskiej}

\section{Streszczenie}

Przedmiotem analizy w tekście są „kultury energetyczne” państw członkowskich Unii Europejskiej (UE-28). W tekście podjęto próbę zweryfikowania zasadności twierdzeń, które wskazują na możliwość pogrupowania państw Unii Europejskiej według szczególnego rodzaju praktyk użytkowania energii.

W celu uszczegółowienia problemu badawczego w pracy przedstawiono następujące pytania badawcze: (1) Czy zasadne jest twierdzenie, że w UE-28 mamy do czynienia ze specyficznymi „,kulturami energetycznymi”? (2) Jeżeli zasadne jest twierdzenie o istnieniu specyficznych „,kultur energetycznych”, to w zwiazku z jakimi cechami następuje podział między państwami $U E-28$ ? Postawione pytania należy związać z zamiarem stwierdzenia istnienia podziału państw w UE-28 na „czyste” i ,brudne” kultury energetyczne. Za podziałem tym przemawiają poszczególne cechy państw członkowskich UE-28, które związane są produkcją, konsumpcją i transformacją energii, np. emisja GHG i zaangażowanie w sektor węglowy.

Do weryfikacji założeń przyjętych $\mathrm{w}$ analizie posłużono się jedną z metod aglomeracyjnych (czyli metoda Warda) i jedną z metod optymalizacji danego grupowania obiektów (czyli metodę $k$-średnich). Ponadto, za pomocą poszczególnych testów, podjęto się analizy różnic w poziomie parametrów pomiędzy wyodrębnionymi skupieniami państw. Dodatkowo, wyodrębniono grupy niezależnych czynników metodą głównych składowych oraz wskazano zakres istotnych różnic w poziomie wyodrębnionych czynników między pogrupowanymi państwami UE-28.

Słowa kluczowe: kultury energetyczne, czyste kultury energetyczne, brudne kultury energetyczne, wskaźniki kultur energetycznych, polityka energetyczna, Unia Europejska, analiza skupień 